Науковий вісник НЛТУ України
Scientific Bulletin of UNFU
$\begin{gathered}\text { http://nv.nltu.edu.ua } \\ \text { https://doi.org/10.36930/40291005 }\end{gathered}$

П. К. Динька

Національний лісотехнічний університет Украӥни, м. Львів, Україна

\title{
ЕКОНОМІЧНА ОСВІТА І НАУКА В НЛТУ УКРАЇНИ: ЗДОБУТКИ, ПРОБЛЕМИ ТА ПЕРСПЕКТИВИ
}

\begin{abstract}
Місією Навчально-наукового інституту екологічної економіки і менеджменту (HНI EЕM) НЛТУ України $\epsilon$ наукове обгрунтування процесів екологізування економіки і всіх сфер життя суспільства, підготовка висококваліфікованих фахівців, компетентних у питаннях втілення вимог сталого розвитку в економічну діяльність. Зусилля колективу Інституту сьогодні зосереджені на дослідженнях актуальних еколого-економічних проблеми освіти і науки, які здійснюються у руслі світових трендів та відповідають засадам сталого розвитку. Викладачі Інституту працюють над проблемами формування екологічної економіки в Україні, шляхами переходу до екологічно обгрунтованих та економічно ефективних методів господарювання, формуванням систем екологічного менеджменту, обліку й аудиту підприємств лісового сектору економіки. Пріоритетним $\epsilon$ науковий напрям досліджень - еколого-економічні проблеми природокористування, підгрунтя яких заклав у 70-80-х роках ХХ ст. д-р екон. наук, проф. Ю. Ю. Туниця. Ці дослідження розвинені та втілені в ідеї і концепції Екологічної Конституції Землі, виголошених від імені України в ООН $(1997,2008,2009,2011)$ та на Світовому саміті "Ріо+20" (2012), а також у рішенні Колегії МОН України щодо екологізації освіти як одного із пріоритетних напрямів діяльності МОН та всіх навчальних закладів незалежно від їх підпорядкування і форм власності (2015). Колектив НHI ЕЕМ працює над освітніми і науковими проблемами, які випереджують сьогоднішні потреби економіки, забезпечує їх спрямованість на потреби майбутньої постіндустріальної інформаційної цивілізації, перехід від відтворювальної системи освіти і науки до випереджувальної.

Ключові слова: екологічна економіка; екологічний менеджмент; еколого-економічна теорія; сталий розвиток; екологізування освіти; екологізування економіки; екологічна компетентність.
\end{abstract}

Вступ. Історична ретроспектива та освітня діяльність. Витоки економічної освіти і науки в Національному лісотехнічному університеті України сягають 40-х років $\mathrm{XX}$ ст., де вони започаткувались на інженерно-економічному факультеті (IEФ), створеному у 1945 р. у складі Львівського лісотехнічного інституту (Tunytsia, 1995). I3 1945 по 1990 рр. інженерно-економічний факультет з невеликими перервами готував інженерів-економістів за двома спеціальностями: "Економіка і організація лісової промисловості і лісового господарства" та "Економіка і організація деревообробної промисловості".

У 1991 р. на ІЕФ розпочалась підготовка фахівців за спеціальністю "Облік і аудит", орієнтованих на особливості облікової політики та оподаткування підприємств лісового господарства, деревообробної та меблевої промисловості, а в 1993 р. у складі ІЕФ було створено відповідну кафедру бухгалтерського обліку, фінансів та аудиту. У 1995 р. на вимогу ринку освітніх послуг через зростання експортно-імпортної діяльності підприємств лісових галузей на ІЕФ розпочалась підготовка фахівців за спеціальністю "Менеджмент зовнішньоекономічної діяльності", а у 1996 р. також було утворено відповідну випускову кафедру.

За активної участі науково-педагогічних працівників, аспірантів і студентів інженерно-кономічного факультету в університеті було реалізовано три проекти за програмою TEMPUS TACIS, 3 яких кожен наступний проект був логічним продовженням і розвитком попереднього (Tunytsia, Zahvoiska \& Maksymiv, 2015):

- Natural Resource Economics (NARECO), T JEP-02169-95, 1996-1997 pp.;

- Environment and Natural Resource Economics (ENARECO), T JEP 10255-96, 1997-2000 pp.;

- Dissemination ENARECO, D_CP-20575-99, 2000-2001 pp.

Метою ичих проектів було розроблення першої в Україні міждисциплінарної магістерської програми з економіки довкілля і природних ресурсів, побудованої на стратегії сталого розвитку.

Викладення основного матеріалу. Унаслідок виконання цих проектів у 1998 р. в університеті вперше в континентальній Європі було розпочато підготовку магістрів економістів-екологів, яку здійснював створений для цієї мети на основі кафедр IEФ центр ENARECO.

У 2004-2013 pp. еколого-економічну освіту і науку в університеті розвивали два навчально-наукові структурні підрозділи. Зокрема, у серпні 2004 р. на виконання Постанови Верховної Ради України від 20 лютого 2003 р. № 565-IV "Про рекомендації парламентських слухань щодо дотримання вимог природоохоронного законодавства в Україні", відповідного рішення Міністерства освіти і науки України, у структурі університету було утворено Інститут екологічної економіки (IEE) та випускова кафедра екологічної економіки (Tunytsia, Zahvoiska, \& Maksymiv, 2015).

\section{Інформація про авторів:}

Динька Павло Кузьмич, канд. екон. наук, доцент, директор HHI EEM. Email: dynka@nltu.edu.ua

Цитування за ДСту: Динька П. К. Економічна освіта і наука в Нлту України: здобутки, проблеми та перспективи. Науковий вісник НЛТУ України. 2019, т. 29, № 10. С. 30-33.

Citation APA: Dynka, P. K. (2019). Economic education and science in Ukrainian national forestry university: achievements, problems and perspectives. Scientific Bulletin of UNFU, 29(10), 30-33. https://doi.org/10.36930/40291005 
У цьому ж році шляхом реорганізації кафедри екології та ландшафтної архітектури було утворено кафедру екології, яка разом з кафедрою екологічної економіки та кафедрою економіки і менеджменту лісових підприємств ввійшла до складу Інституту екологічної економіки.

Кафедри економіки і менеджменту деревообробних підприємств, менеджменту зовнішньоекономічної діяльності, обліку і аудиту, економічної теорії та вищої математики продовжували освітню і наукову діяльність у складі економічного факультету (ЕФ). У 2011 р. на ЕФ розпочалась підготовка бакалаврів за напрямом "Економіка підприємства".

У березні 2014 р. шляхом об'єднання Інституту екологічної економіки i економічного факультету та приєднання до студентів денної форми навчання цих підрозділів контингенту студентів заочного факультету було утворено Навчально-науковий інститут екологічної економіки і менеджменту (НHI ЕЕМ).

Місією Навчально-наукового інституту екологічної економіки і менеджменту є наукове обгрунтування процесів екологізування економіки і всіх сфер життя суспільства, підготовка висококваліфікованих фахівців, компетентних у питаннях втілення вимог сталого розвитку в економічну діяльність.

Сьогодні до складу ННI ЕЕМ входять вісім кафедр: екологічної економіки, менеджменту організацій і адміністрування, економіки підприємства, менеджменту зовнішньоекономічної діяльності, обліку і аудиту, екології, економічної теорії, вищої математики. Із цих кафедр шість кафедр є випусковими.

Освітньо-виховний процес в інституті забезпечують понад вісімдесят науково-педагогічних працівників. Серед них - один академік НАН України, д-р екон. наук, проф. Туниця Ю. Ю., десять докторів наук, професорів та понад шістдесят кандидатів наук, доцентів.

На 01.10.2018 р. у ННІ ЕЕМ за чотирма спеціальностями і шістьма освітніми програмами навчалося 802 студенти, із них: 431 особа- за денною формою, 371 особа - заочно. На денній формі 272 особи навчалось за держзамовленням, 159 осіб - за кошти фізичних і юридичних осіб, на заочній формі - 40 осіб навчалось за держзамовленням, 331 особа - за кошти фізичних i юридичних осіб.

ННI ЕЕМ активно розширює провадження освітньої діяльності, започатковує нові спеціальності та освітні програми. Зокрема, останніми роками проведено первинну акредитацію підготовки студентів за першим (бакалаврським) рівнем напряму "Економіка підприємства", ліцензування та первинну акредитацію підготовки студентів за ОКР "Спеціаліст" та рівнем "Магістр" освітньої програми "Економіка підприємства", а також ліцензування та первинну акредитацію спеціальності (освітньої програми) "Облік і оподаткування" за другим (магістерським) освітнім рівнем. Також було розширено провадження ліцензійної діяльності за спеціальностями "Екологія" і "Менеджмент" на магістерському рівні та "Економіка" на бакалаврському рівні.

Iз 2017/2018 н. p. у НHI ЕЕМ розпочато підготовку фахівців за першим (бакалаврським) рівнем за освітньою програмою "Економіка довкілля і природних ресурсів". Розроблено обгрунтування та навчально-методичне забезпечення та запроваджено із 2018/2019 н. p. освітню програму "Міжнародна економіка" за пер- шим (бакалаврським) і другим (магістерським) рівнями освіти. Розроблено обгрунтування та навчально-методичне забезпечення та запроваджено із 2018/2019 н. p. спеціалізації "Менеджмент туризму", "Заповідна справа", "Менеджмент митної діяльності", "Менеджмент міжнародних проектів" за другим (магістерським) рівнем освіти.

У ННІ ЕЕМ послідовно продовжується поглиблення екологізування освітнього процесу, основними напрямами якого $є$ (Tunytsia, et al., 2015):

- екологізування всіх складових освітнього процесу;

• екологізування наукових досліджень викладачів і науководослідної роботи студентів;

- урахування екологічних імперативів у господарській діяльності університету та студентського містечка;

- інтегрування імперативу сталості у виховну роботу.

У процесі навчання у студентів НHI ЕЕМ системно формується їх еколого-економічна компетентність як динамічна комбінація екологічних, економічних знань, вмінь і практичних навичок, екоцентричних світоглядних засад, еколого-економічного мислення, професійних і громадянських якостей, морально-етичних цінностей, яка визначає здатність випускника інституту успішно здійснювати професійну та подальшу навчальну діяльність та $є$ результатом навчання за відповідною освітньо-професійною (освітньо-науковою) програмою на певному рівні вищої освіти.

Визначальною складовою еколого-економічної компетентності і основною метою екологізування освітньої діяльності $є$ формування еколого-економічного мислення студентів як одного із провідних видів фахового мислення.

Розвиток наукових досліджень. Зусилля колективу Інституту сьогодні зосереджені на дослідженнях актуальних еколого-економічних проблеми лісотехнічної освіти і науки, які здійснюються у руслі світових трендів та відповідають засадам сталого розвитку. Викладачі Інституту працюють над проблемами формування екологічної економіки в Україні, шляхами переходу до екологічно обгрунтованих та економічно ефективних методів господарювання, формуванням систем екологічного менеджменту, обліку і аудиту підприємств лісового сектору економіки.

Пріоритетним серед них є науковий напрям досліджень - еколого-економічні проблеми природокористування, підгрунтя яких заклав у 70-80-х роках д-р екон. наук, проф. Ю. Ю. Туниця на кафедрі економіки і організації лісової промисловості та лісового господарства. Проф. Ю. Ю. Туниця на прикладі принципів екологоекономічного оцінювання лісових ресурсів сформулював сутність еколого-економічного вчення, яке на противагу традиційній ринковій чи командно-адміністративній економіці, має на меті розроблення ефективних методів урахування екологічних факторів в економічних системах як їх органічних складових (Tupytcia, 1976, 1980).

Ці дослідження продовжуються на кафедрі екологічної економіки та інших кафедрах інституту. Вони знайшли відображення в:

- ідеї і концепції Екологічної Конституції Землі (Tunytsia, 2011), виголошених від імені України в ООН (1997, 2008, 2009, 2011) та Світовому саміті "Pio+20" (2012);

- рішенні Колегії МОН України щодо екологізації освіти як одного із пріоритетних напрямів діяльності МОН та всіх 
навчальних закладів незалежно від їх підпорядкування i форм і власності (Ekolohizatsiia, 2015).

Визнано результати дослідників школи, отримані під час виконання таких науково-дослідних робіт:

- "Предметна сфера економічної теорії у суспільстві сталого розвитку", № держреєстрації 011U002653;

• "Теоретико-методологічні засади екологізації освіти як чинника формування людського капіталу для сталого розвитку", № держреєстрації 0115U002315;

- "Формування економічного механізму забезпечення суспільства послугами екосистем як підгрунтя трансформації галузевої політики і менеджменту у лісовому господарстві", № держреєстрації $0117 \mathrm{U} 002337$.

У другій половині 90-их років на кафедрі економіки і менеджменту лісових підприємств проф. I. М. Синякевич (Syniakevych, 2005) заклав теоретичні основи лісової політики як наукового підгрунтя для реформування лісового господарства в Україні. Ці дослідження продовжують д-р екон. наук проф. А. М. Дейнека, д-р екон. наук І. П. Соловій та інші представники львівської школи лісової політики (Syniakevych, et al., 2008). Науковцями НHI EЕM теоретично обгрунтували принципи лісової політики, інструменти лісової політики, напрацювали ефективні шляхи реформування лісового господарства.

Провідним напрямом наукових досліджень кафедри менеджменту ЗЕД, які здійснюються під керівництвом д-р екон. наук проф. Т. Ю. Туниці, є "Концептуальні основи програми розвитку зовнішньоекономічної діяльності лісових, деревообробних, целюлозно-паперових та меблевих підприємств". У жовтні 2016 р. кафедрою проведено Міжнародну науково-практичну конференцію "Актуальні проблеми та перспективи розвитку зовнішньоекономічної діяльності в умовах глобалізації".

Важливим напрямом наукової діяльності кафедри економіки підприємства $є$ дослідження економічних проблем, об'єднаних у тему: "Оптимальний розвиток та реформування деревообробної промисловості України в умовах переходу до ринкової економіки на засадах сталого розвитку" (науковий керівник напряму д-р екон. наук проф. Г. С. Шевченко). Кафедра також має значний теоретичний і практичний доробок щодо впровадження в освітній процес активних методів навчання.

Наукова робота кафедри обліку і аудиту зорієнтована на дослідження сучасних проблем обліку, аналізу, контролю й оподаткування в лісовому секторі економіки України з урахуванням екологічної складової. Загальна кафедральна тема наукових досліджень "Проблеми екологізації обліку, аналізу і контролю в Україні" (науковий керівник д-р екон. наук проф. П. М. Гарасим) відповідає пріоритетним напрямам розвитку науки i техніки на період до 2020 р.

До наукових досліджень та Міжнародних інтернетконференцій кафедрою обліку і аудиту широко залучаються студенти університету та інших навчальних закладів з України та з інших країн.

Кафедра екології розробляе нову багатофункціональну модель екологізування ведення лісового господарства на типологічній основі і лісокористування 3 урахуванням ландшафтного та басейнового (водозбірного) принципів, які об'єднують екологічні, економічні й соціальні цілі господарювання, а також наукові засади наближеного до природи лісівництва як підгрунтя для сталого ведення лісового господарства (науковий керівник д-р с.-г. наук, проф. Л. І. Копій).

Колектив кафедри економічної теорії здійснює наукову роботу в рамках кафедральної ініціативної теми "Проблеми формування нової економічної системи України в умовах глобалізації".

На кафедрі математики проводять наукові дослідження за напрямами: міцність та довговічність тіл, послаблених різного роду концентраторами напружень; математичне моделювання контактної взаємодії пар тертя та процесу розколювання деревини. У 2015 р. професор кафедри Процах Н. П. захистив докторську дисертацію на тему "Мішані задачі для нелінійних еволюційних рівнянь та ультрапараболічні варіаційні нерівності".

Із березня 2014 р. колектив ННI ЕЕМ опублікував понад 40 монографій із актуальних еколого-економічних проблем, 14 навчальних посібників, майже 400 статей у фахових виданнях (із них понад $30-$ у наукометричній базі даних "Scopus" та чотири - y "Web of Science"). До виконання досліджень також активно долучаються студенти інституту. За їх участю опубліковано понад 100 наукових статей, із них 15 статей опубліковано студентами одноосібно.

Кафедрами інституту укладено понад 40 угод про науково-технічне та міжвузівське співробітництво із зарубіжними університетами економічного, природничого та лісотехнічного профілю. У рамках виконання міжнародних інститутських та кафедральних програм i проектів зі сталого екосистемного менеджменту та лісової політики вже пройшли навчання за кордоном десять студентів. Двадцять викладачів та аспірантів пройшли довготривалі стажування у провідних університетах світу, із них чотири особи - за програмою ім. Фулбрайта.

В Інституті запроваджуються спільно із провідними європейськими університетами міжнародні магістерські програми із видачею їх випускникам подвійних дипломів, що сприятиме підвищенню престижності навчання в HНI EЕM та популяризуватиме еколого-економічні спеціальності на насиченому висококонкурентному ринку освітніх послуг України. EEM:

Перспективні напрями діяльності колективу ННI

1. Формування системи еколого-економічної освіти як безперервної, орієнтованої на опанування студентами екологічних та економічних компентентостей, які $є$ підгрунтям для формування еколого-економічної компетентності та фахового еколого-економічного мислення;

2. Забезпечення випереджуючого сьогоднішні потреби економіки розвитку освіти і науки, їх спрямованості на проблеми майбутньої постіндустріальної інформаційної цивілізації, перехід від відтворювальної системи освіти до випереджувальної;

3. Консолідування зусиль колективу на пріоритетних наукових дослідженнях, забезпечення їх органічного взаємозв'язку з освітньою діяльністю;

4. Підготовка науково-педагогічних працівників вищої кваліфікації для якісного кадрового забезпечення освітніх програм за наявними і перспективними спеціальностями;

5. Формування контингенту студентів з урахуванням вітчизняних і світових тенденцій на ринку праці, демогра- 
фічної ситуації та зростаючої конкуренції у внутрішньому і зовнішньому освітньому середовищі;

6. Забезпечення навчання здобувачів вищої освіти на засадах індивідуалізації та диференціації шляхом створення можливостей для реалізації пошуку студентами індивідуальної освітньої траєкторії.

\section{References}

Ekolohizatsiia. (2015). Rishennia Kolehii MON Ukrainy vid 27.11.2015 r. "Pro ekolohizatsiiu vyshchoi osvity z metoiu pidhotovky fakhivtsiv dlia staloho rozvytku". Retrieved from: http://mon.gov.ua/content/Новини/2015/12/30/10-5-4.zip. [In Ukrainian].

Syniakevych, I. M. (2005). Lisova polityka. Lviv: IZMN, 223 p. [In Ukrainian].

Syniakevych, I. M. (Ed.), Solovii, I. P., Vrublevska, O. V., et al. (2008). Lisova polityka: teoriia i praktyka. Lviv: LA "Piramida", 612 p. [In Ukrainian].
Tunytsia, Yu. Yu. (Ed.), Zahvoiska, L. D., \& Maksymiv, L. I. (2015). Ekonomika dovkillia i pryrodnykh resursiv. Informatsiinyi paket spetsialnosti. Lviv: Afisha, 372 p. [In Ukrainian].

Tunytsia, Yu. Yu. (Ed.). (1995). Ukrainskyi derzhavnyi lisotekhnichnyi universytet. Lviv: NVP "Meta", 182 p. [In Ukrainian].

Tunytsia, Yu. Yu. (Ed.). (2011). Ekolohichna Konstytutsiia Zemli. Metodolohichni zasady. Lviv: RVV NLTU Ukrainy, 440 p. [In Ukrainian].

Tunytsia, Yu. Yu., Adamovskyi, M. H., Borys, M. M., Kraievskyi, S. N., \& Mahazynshchykova, I. P. (2015). Ekolohizatsiia osvity yak kliuchovyi faktor pidhotovky fakhivtsiv dlia staloho rozvytku. Scientific Bulletin of UNFU, 25(10), 348-356. https://doi.org/10.15421/40251053

Tupytcia, Iu. Iu. (1976). Ekonomicheskie problemy kompleksnogo ispolzovaniia $i$ okhrany lesnykh resursov. Lviv: High school, 212 p. [In Russian].

Tupytcia, Iu. Iu. (1980). Ekologo-ekonomicheskaia effektivnost prirodopolzvaniia. Moscow: Science, 168 p. [In Russian].

P. K. Dynka

Ukrainian National Forestry University, Lviv, Ukraine

\section{ECONOMIC EDUCATION AND SCIENCE IN UKRAINIAN NATIONAL FORESTRY UNIVERSITY: ACHIEVEMENTS, PROBLEMS AND PERSPECTIVES}

The mission of Educational and Scientific Institute of Ecological Economics and Management (ESI EEM) of Ukrainian National Forestry University (UNFU) is scientific substantiation of the processes of ecologization of the economy and all fields of life in society, training of highly qualified professionals with competency in implementation of sustainable development requirements into economic activity. Today, the work of the academic staff of the Institute is aimed at research of actual environmental and economic problems of education and science in the framework of world trends and the concept of sustainable development. Lecturers and professors of the Institute work on problems of forming ecological economics in Ukraine, transition to environmentally substantiated and economically efficient methods of activity, forming systems of ecological management and audit of the enterprises in forest sector of economy. Environmental and economic problems of nature use are the priority scientific direction of research the basis of which was laid in1970 s-1980 s by Doctor of Economics, Professor Yu.Yu. Tunytsya. This research was developed and embodied into the ideas and concept of the World Environmental Constitution, presented on behalf of Ukraine in the UN (1997, 2008, 2009, 2011) and Earth Summit "Rio+20" (2012), and also in decision of the Collegium of the Ministry of Education and Science (MES) of Ukraine for ecologization of education as one of the priority activities of MES and all educational institutions disregard of their subordination and forms of ownership (2015). Personnel of ESI EEM works on educational and scientific problems, which advance modern needs of economy, provides their direction to the needs of the future post-industrial informational civilization, transition from reproductive system of education and science to the advancing one.

Keywords: ecological economics; ecological management; ecological and economic theory; sustainable development; ecologization of education; ecologization of economy; environmental competency. 